\title{
Tax bunching by owners of small corporations
}

Leon J.H. Bettendorf

Arjan Lejour

Maarten van ‘t Riet 



\title{
Tax bunching by owners of small corporations
}

\author{
Leon J.H. Bettendorf* Arjan Lejour ${ }^{\dagger} \quad$ Maarten van ’t Riet $\ddagger$
}

14 March 2016

\begin{abstract}
In the Netherlands owners of small corporations face taxation of corporate, labour and capital income. Taxation of the latter may be deferred. We study their options for income shifting using bunching techniques. Based on individual tax records over the period 2007-2011 we report four main findings. The first is that the distribution of gross labour income strongly peaks at the legal 'minimum' level. Second, taxable labour income bunches at the cut-offs of the tax brackets. The elasticity of taxable income at the top tax cut-off ranges from 0.06 to 0.11 . Third, we show that distributed profits strongly responded to the temporary tax cut from 25 to $22 \%$ in 2007 , which doubled tax revenues on dividends. Fourth, using a Heckman selection model we find that the size of own equity has a positive effect on the probability of distributing profits and the size. We reconfirm the importance of intertemporal income shifting for business owners.
\end{abstract}

Keywords: bunching, small corporations, taxable income, income shifting.

${ }^{*}$ CPB Netherlands Bureau for Economic Policy Analysis. Corresponding author: CPB, P.O. Box 80510, 2508 GM, The Hague, The Netherlands. Phone: +31-70-3383390. E-mail: L.J.H.Bettendorf@cpb.nl.

${ }^{\dagger}$ CPB Netherlands Bureau for Economic Policy Analysis. E-mail: A.M.Lejour@cpb.nl.

${ }^{\ddagger}$ CPB Netherlands Bureau for Economic Policy Analysis. E-mail: M.van.t.Riet@cpb.nl. We thank Bas Jacobs and Hendrik Vrijburg for their bunch of comments and suggestions. 


\section{Introduction}

The taxable income of self-employed individuals is commonly found to respond more strongly to changes in marginal tax rates than the taxable income of wage earners (see e.g. Saez (2010) and Chetty et al. (2011)). The self-employed are better able to avoid an increase in tax rates because they face less frictions in shifting income to forms that are taxed at a lower rate. Devereux et al. (2014) demonstrate this by analysing income shifting between corporate and personal taxation; Harju and Matikka (2014) for shifting between wages and dividends and le Maire and Schjerning (2013) for intertemporal shifting.

This paper analyses shifting between tax bases by owners of small corporations in the Netherlands using individual tax filings. ${ }^{1}$ Managing directors who own at least $5 \%$ of a corporation fall in a specific tax regime. These owners are abbreviated as DGA (Directeur-GrootAandeelhouder in Dutch). ${ }^{2}$ DGAs face different types of taxation: taxation of corporate income (according to a two-rate structure), progressive taxation of labour income, proportional taxation of dividend income and proportional taxation of personal wealth (above a threshold). As a consequence, they can exploit several opportunities to minimise the tax burden by shifting income between fiscal partners, between labour and dividend income and, in particular, over time.

We report four findings, using individual tax records of DGAs and the firms they own for the years 2007-2011. First, DGAs have an incentive to report a low wage income to avoid the progressive taxation of labour income. A reference level is specified and although this is not an absolute legal minimum, many DGAs seem to interpret it in this way. The McCrary-estimate of the discontinuity shows that the density of gross wage income strongly peaks exactly at the reference level for all years. Second, taxable labour income bunches at the cut-offs of the tax brackets, in particular at the top tax cut-off. The elasticity of taxable income ranges from 0.06 to 0.11. In line with le Maire and Schjerning (2013), we show that bunching at the top tax bracket cut-off is mainly driven by intertemporal income shifting and less by atemporal shifting. Third, we analyse the low frequency of dividend payments that are taxed at a flat rate. We exploit the temporary reduction of the tax rate in 2007 to demonstrate the strong responses by DGAs. The 3\%-lower rate caused

\footnotetext{
${ }^{1}$ This paper does not deal with the effects of the taxation system on the choice of the organisational form. Differences in the tax treatment of employees, owners of corporations and owners of non-corporate firms are documented in Commissie inkomstenbelasting en toeslagen (2013) and Ministry of Finance (2014b). For an overview of the empirical literature, see Crawford and Freedman (2010).

${ }^{2}$ Since a major part of these firms has no employees, their owners can be considered self-employed. However, not all these owners work (full-time) in their own firm and not all the self-employed choose for incorporation.
} 
substantial bunching of distributed profits at the upper end of the tax bracket, resulting in a sharp increase in tax revenues. Next, using a Heckman selection model we find that the size of own equity is an important determinant for both the decision to distribute profits and the size of the dividends.

The responses of self-employed and business owners to taxes are estimated in two types of studies. The first type uses the bunching method. Saez (2010) finds that the bunching around the first threshold of the EITC-schedule in the US can be entirely attributed to recipients with self-employment income. The elasticity of income of self-employed and pure wage earners is estimated around one and zero, respectively. Bunching is not found for the other EITC thresholds. Furthermore, the bunching evidence at the kink points of the federal income tax schedule does not seem different between wage earners and self-employed.

Chetty et al. (2011) find that taxable income of Danish self-employed bunches at the middle tax bracket cut-off but in particular at the top tax cut-off, whereas the distribution is smooth for wage earners. Using the same data, le Maire and Schjerning (2013) show that more than half $(50-70 \%)$ of the estimated bunching is driven by income shifting, in particular using retained earnings. ${ }^{3}$ When the possibility of income shifting is neglected, the taxable income elasticity is estimated in the range of $0.43-0.53$. Distinguishing between real responses and income shifting reduces the structural elasticity to the range of $0.14-0.20$. As a consequence, the elasticity is not a sufficient statistic for the deadweight loss when not corrected for income shifting.

Bastani and Selin (2013) apply the bunching method to kink points in the tax schedule in Sweden. In contrast to wage earners, the density of taxable income of self-employed shows significant excess mass at the first kink point, where the marginal tax rate is increased by a maximum of $23 \%$ points. ${ }^{4}$ However, the implied compensated elasticity of taxable earnings is small (0.018). When the sample is restricted to 'purely' self-employed, i.e. those who only report business income from the firm they own, the elasticity increases to 0.052 . In addition, bunching also becomes significant at the second kink, where the marginal tax rate increases by $5 \%$ points, with an elasticity of 0.012 .

The second type of empirical studies uses panel regressions. Kleven and Schultz (2014) use panel data to estimate effects of changes in tax rates following various reforms in

\footnotetext{
${ }^{3}$ Whereas self-employed are broadly defined by Chetty et al. (2011) as persons who have reported positive self-employment income, le Maire and Schjerning (2013) limit the sample to persons whose primary occuputation was self-employment. Other means of income shifting include transfers to assisting spouses, pension contributions and classifications as capital income.

${ }^{4}$ The group of self-employed consists of owners of closely-held corporations, sole proprietors and partnership owners.
} 
Denmark. They find (in Table 8) that the broad income (this is labour plus capital income, before tax deductions) of the self-employed responds more strongly to the net-of-tax rate on labour income than broad income of wage earners (elasticity of 0.084 versus 0.052 ). The elasticity to the net-of-tax rate on capital income is significant for wage earners (0.014) but not for the self-employed. Similar results are found for taxable income (i.e. after tax deductions). ${ }^{5}$

Harju and Matikka (2014) examine responses by owners of privately held corporations to dividend and wage income taxes in Finland, using panel regressions. In particular, they distinguish between real responses and income shifting between tax bases. They find that the dividend tax base significantly reacts to the dividend tax rate, whereas the wage tax base is not significantly related to its own rate. Moreover, the cross-elasticity of both bases is significant, indicating that income shifting accounts for a large part of the behavioural responses. The marginal excess burden of taxation is substantially lower when the income shifting effect is included in the calculation. ${ }^{6}$

Alstadsaeter and Jacob (2015) use a dif-in-dif regression to estimate the effect of a cut in the dividend tax rate by 10 percentage points on income shifting for Sweden. They find that owner-managers of closely held corporations responded by shifting about $6 \%$ of total gross income from labour income to dividends, when compared to the unaffected group of owners of unincorporated businesses. In contrast, their total gross income was not significantly increased.

The paper is structured as follows. In the next section we describe the tax system, in particular the taxation of DGAs and the corporations they own. Section 3 presents the two datasets stemming from different types of tax filings. Section 4 discusses the bunching results found for the wage income declared by DGAs around its minimum level. Section 5 reports the results for labour income around the cut-offs of the tax bracket. The taxation of non-labour income of DGAs is studied in Section 6. Section 7 discusses possible determinants of profit distribution. Section 8 concludes.

\footnotetext{
${ }^{5}$ They also present evidence on shifting between labour and capital income for tax avoidance purposes but unfortunately this finding is only reported for the total sample of wage earners and self-employed.

${ }^{6}$ In addition, they perform a bunching analysis. The finding of significant excess mass at a kink in the dividend tax schedule and insignificant bunching at kinks in the income tax schedule supports the results of the panel regression analysis.
} 


\section{The Dutch tax system and income shifting possibilities for DGAs}

We describe the tax system of the Netherlands with an eye to the income shifting possibilities for owners of small corporations (see Van den Bos et al., 2012). The business of the DGA faces corporate income taxation and its owner personal income taxation. The description applies to the period 2007-2011, for which we have tax record data.

\subsection{The tax system in a nutshell}

Corporate income is taxed according to a two-rate structure. Small and medium-size corporations are stimulated with a lower tax rate of $20 \%$ for taxable income bases below a threshold of 200k euro (from 2009 onwards). When the base exceeds the threshold, the higher marginal rate of $25.5 \%$ applies (25\% in 2011). For the parameters of the tax system see Table 1.

With the income tax reform of 2001 the Netherlands abandoned its synthetic income tax system in which labour and capital income was added together and taxed progressively (Cnossen and Bovenberg, 2001). The reform introduced three income components, called 'boxes', which are taxed differently.

In the first box labour income is progressively taxed. Added to the income in this box is the net, fictitious, income from an owner-occupied house. Interest payments on mortgage debt for this house are deductable. Four tax brackets apply and the top marginal rate is $52 \%$. DGAs need to specify a salary in this box 1 . Different rules govern the determination of this salary, discussed below.

The second box of the personal income tax is specifically targeted at DGAs. Here they have to report distributed profits from their own incorporated businesses, when they hold at least $5 \%$ of the shares. Sale of the company, or part of its shares, is also taxed in this box. It has a flat rate of $25 \%$, which was temporarily reduced to $22 \%$ in 2007 for tax bases not exceeding $250 \mathrm{k}$ euro.

Finally the third box applies to all other capital income. A flat-rate return of $4 \%$ is assumed, on all categories of wealth, which is taxed at a rate of $30 \%$. Thus, box 3 amounts, de facto, to a wealth tax of $1.2 \%$. It applies to savings, stocks, second homes and to investments with less than 5\% ownership. Excluded from taxable wealth is the value of the owner-occupied house, which is included in box 1 . Wealth below an individual threshold of about $21 \mathrm{k}$ euro is exempt from taxation. 


\subsection{The DGA reference salary}

Figure 1 depicts the taxation of DGAs, starting from corporate income before taxation and before remuneration for the services of the managing director and (partial) owner of the company. The salary the DGA pays to himself is subject to rules and approval of the tax authority. The rules state that the salary should at least be $70 \%$ of what is 'commonly' paid to managing directors of similar companies: the reference salary. This reference has a minimum level (41k euro in 2010 and 2011). In practice, many DGAs seem to consider this level as an absolute minimum, whereas the correct interpretation is that the burden of proof shifts from the tax authority to the DGAs at this level. A DGA reporting a lower salary has to provide a plausible explanation for this, for example, because he worked parttime as a DGA or because he started the business half way through the year. For incomes above this level the burden of proof, formally, rests with the tax authority. In practice it may involve negotiations with the DGA, with the bottom line being that the tax authority is unlikely to accept a low DGA salary when the corporate income is consistently high.

The DGA salary reported for income tax (box 1) may be virtual, in the sense that it is not required that the DGA actually receives this labour income and that the money is taken out of the company. The box 1 taxes on the virtual salary have to be paid, however.

\subsection{Labour versus capital income}

The actual salary of the DGA reduces the base for corporate income taxation, as may losses of previous years. The same applies for contributions to external pension insurance. The DGA may also opt for a pension provision within his business. The accumulated pension reservations are a liability on his balance sheet. This option is governed by an elaborate tax code. In general, since no corporate taxes have been paid on this amount, the tax authority will check whether liabilities are sufficient to meet the pension obligations.

Following the flow of corporate income, see Figure 1, profits after taxation may be distributed as dividends to the owners or may be retained in the corporation. Dividends imply taxation in box 2 and retained earnings mean that taxation is deferred. The first possibility of income shifting is therefore between labour income, taxed in box 1, and dividend income, possibly deferred, taxed in box 2 . The second possibility of shifting is between taxation in box 2 and box 3 .

Figure 2 shows the marginal tax rates of the personal income tax (box 1), and the combination of the corporate income tax (CIT) and the owner-dividend tax. The low CIT rate of $20 \%$ with the dividend rate of $25 \%$ gives a combined rate of $40 \%$; with the high CIT rate of $25.5 \%$ (up to 2010) this amounts to $44.125 \%$. 
Taxation in the first bracket of box 1 is less than the combined taxation on dividend income. However, whether the DGA can report such a low labour income depends on the tax authority. The second and third tax bracket both have a rate of $42 \%$, which is below the combined rate with the higher CIT rate. The latter applies to corporate incomes over the threshold of 200k euro; in this case it is unlikely that the tax authority will accept DGA salaries compatible with the these tax brackets. When the top marginal rate of $52 \%$ applies dividend income is always preferred over labour income. In addition the DGA has the option to defer distribution of profits, and thus its taxation, so the combined rates used in the comparison above must be seen as an absolute upper bound.

There is another interesting interaction between the taxation of labour and corporate income of DGAs. When the corporation has sufficient capital the owner may borrow from his own business. The tax code demands that interest payments must be at a market rate. The business will have to pay taxes over the interest income. The profitability for the DGA arises when the loan is used for the purchase of his house; then the interest payments are deductable from his labour income tax base and exactly the same comparisons from above apply.

The owner can exploit another arbitrage possibility by borrowing from the business to save or invest privately. Interest payments would again be taxed as corporate income. Savings however will face box 3 taxation of $30 \%$, but on a flat rate of return of $4 \%$. Thus with higher actual rates of return, assumed to be the same for corporate and private investments, the tax burden will be lower with the savings or investments in box 3 .

With the reform of 2001 the Dutch tax system became a schedular tax system combining progressive taxation of labour income with a lower tax rate on profit income of DGAs and a de facto wealth tax. Boadway (2004) warns that 'actual income tax systems inevitably end up excluding some sorts of income and taxing others preferentially leaving opportunities for arbitrage, or evasion, undermining the integrity of the tax system'. The preferential treatment and the opportunities for arbitrage in the Dutch system are clearly present with box 2. For instance, specialists in the legal, medical and academic professions have incorporated and rent out their labour services. In this way they receive, at least a part of, their income as lower-taxed dividend in box 2 instead of higher-taxed labour income.

The separation of labour and capital income is considered notoriously difficult (Boadway, 2004). The Dutch tax system resembles the dual income tax system of the Nordic countries because of the box structure. But where in the Dutch system labour income is determined first, i.e. the DGA reference salary, in the Nordic countries it is the other way around: a fictitious capital income is determined first (Sørensen, 2010; Jacobs, 2015). 
Moving to the Nordic system would not entirely eliminate arbitrage but it would make the treatment of DGAs and employees more equal (Cnossen, 2014).

\subsection{Intertemporal income shifting}

There are several motives for the DGA to defer the distribution of profits and, hence, taxation. Foremost of all, the capital may be desired for the operation of the business itself. Next, the DGA may see the value of his business assets as pension wealth. Or alternatively he may want to bequest (a part of) the business to his children, which also depends on the taxation of bequests and gifts.

There are also tax-related motives. The DGA may anticipate a 'tax holiday'; there was one in 2007, when the box 2 tax rate was set to $22 \%$ instead of the regular $25 \%$, for distributed profits up to 250k euro. The same tax cut was effective in 2014. Taxation can even be avoided all together by emigration of the DGA, although this route was closed in September 2015. After 10 years the tax authority will, when certain conditions are met, cancel the tax liability. Finally, there is a tax code for business succession with possibilities of exemption and deferral.

In sum, we can identify a host of motives for intertemporal income shifting for the DGA. Of the tax related motives some are governed by complex code, giving rise to a vibrant fiscal consultancy practice. 
Table 1: The tax system

\begin{tabular}{lrrrrr}
\hline & 2007 & 2008 & 2009 & 2010 & 2011 \\
\hline $\begin{array}{l}\text { Corporate income - brackets } \\
\text { bracket (in euros) }\end{array}$ & 25000 & 275000 & 200000 & 200000 & 200000 \\
medium bracket & 60000 & & & & \\
$\begin{array}{l}\text { Corporate income - tax rates } \\
\text { 1st bracket }\end{array}$ & 20 & 20 & 20 & 20 & 20 \\
medium bracket & 23.5 & & & & \\
2nd bracket & 25.5 & 25.5 & 25.5 & 25.5 & 25 \\
& & & & & \\
Reference salary (in euros) & 40000 & 40000 & 40000 & 41000 & 41000 \\
& & & & & \\
Box 1 - brackets & & & & & \\
1st bracket (in euros) & 17319 & 17579 & 17878 & 18218 & 18628 \\
2nd bracket (in euros) & 31122 & 31589 & 32127 & 32738 & 33436 \\
3rd bracket (in euros) & 53064 & 53860 & 54776 & 54367 & 55694 \\
Box 1 - tax rates & & & & & \\
1st bracket* & 33.65 & 33.60 & 33.5 & 33.45 & 33 \\
2nd bracket* & 41.40 & 41.85 & 42 & 41.95 & 41.95 \\
3rd bracket & 42 & 42 & 42 & 42 & 42 \\
4th bracket & 52 & 52 & 52 & 52 & 52
\end{tabular}

Box 2

bracket (in euros)

250000

low rate

22

standard rate

25

25

25

25

25

Box 3

\begin{tabular}{lrrrrr} 
exemption (in euros) & 20014 & 20315 & 20661 & 20661 & 20785 \\
tax rate & 1.2 & 1.2 & 1.2 & 1.2 & 1.2 \\
\hline
\end{tabular}

* inclusive of social security contributions. 
Figure 1: Simplified flow of corporate income and current taxation

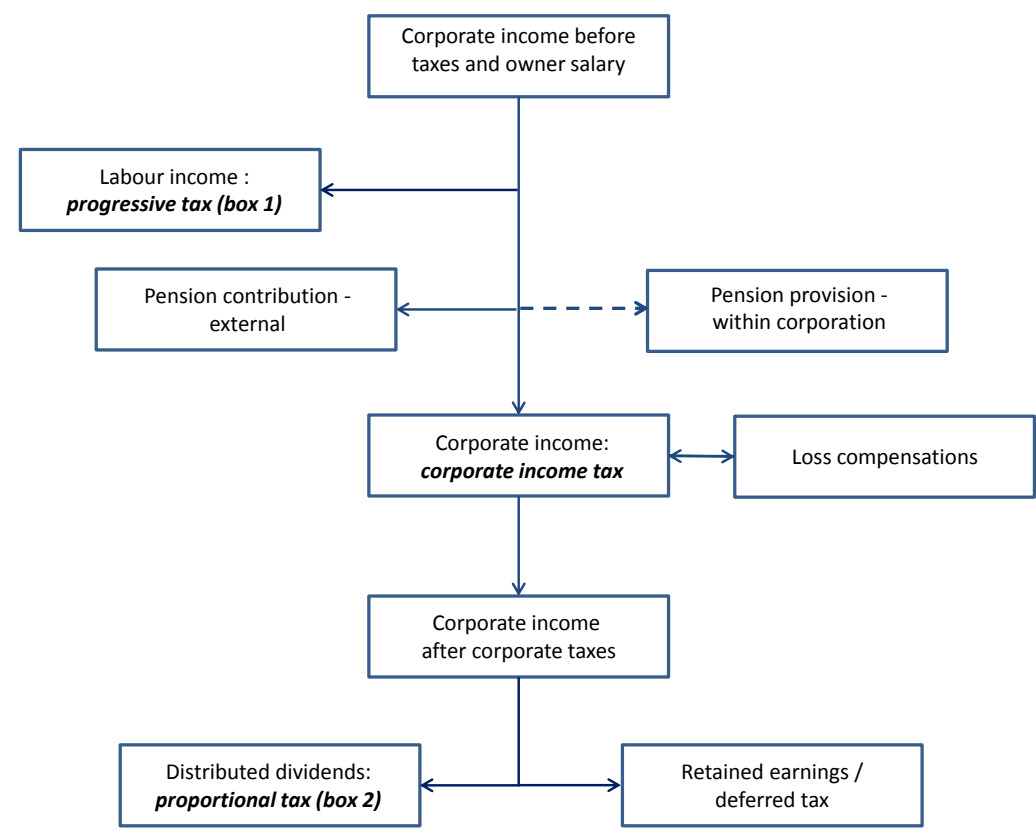

Figure 2: Marginal tax rates PIT and CIT plus dividend tax (2011)

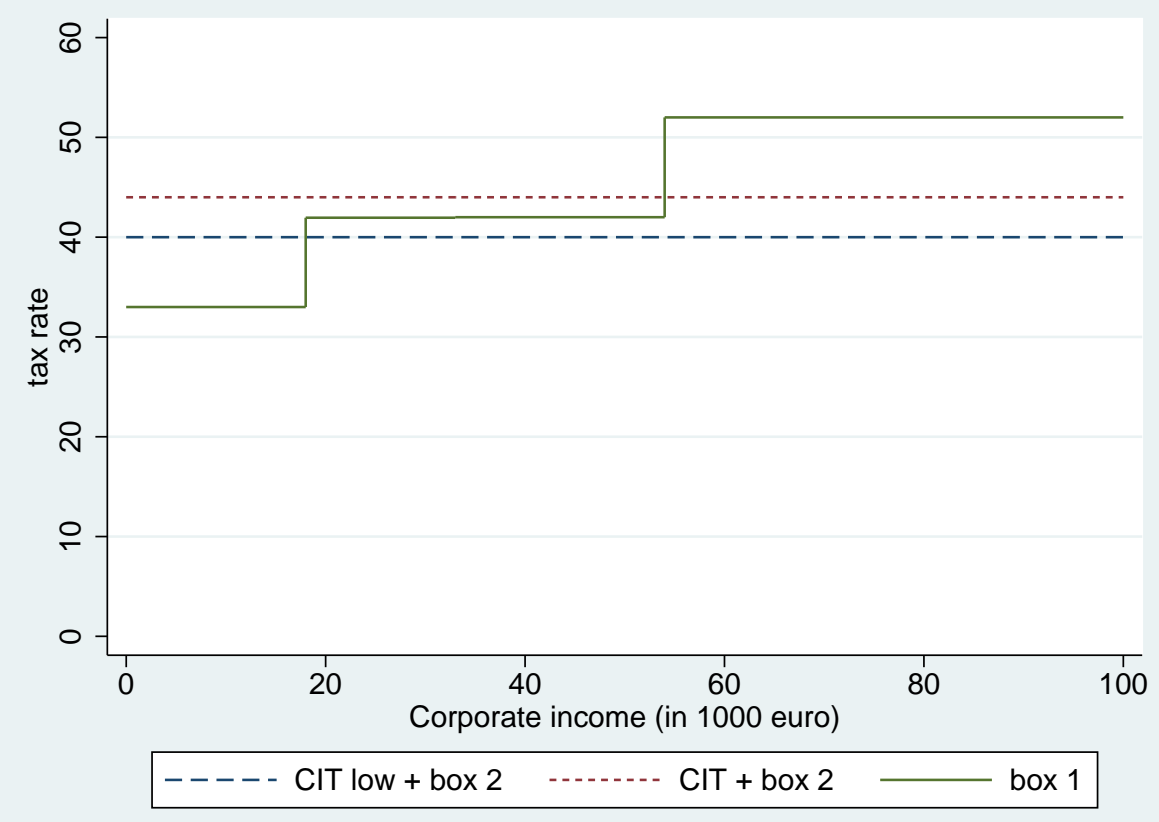




\section{The data}

We use individual tax declarations made by all DGAs and the firms they own for the years 2007-2011. We have 2 datasets. The first dataset contains the variables found in the income tax declarations of DGAs, while the second dataset concerns the corporate income tax declarations of firms who (partially or fully) are owned by one or more DGAs. This dataset contains no companies that are $100 \%$ owned by a holding company; only firms with at least one natural person as owner are included. We are able to link both datasets for a majority of DGAs and firms.

The descriptive statistics in Table 2 show that the number of DGAs and the number of firms they own steadily increase in the period considered. The median value of gross labour income remains rather stable. Due to the low frequency of dividend payments, the median value equals zero. For observations with strictly positive dividends, the high value in 2007 is striking due to the temporary modest reduction of the tax rate(see Section 6). The relatively low median firm's wealth (including pension reserves) indicates that DGAs mainly own small corporations. The equity of these small firms hardly changes over time, as shown by the small median changes in the last row.

Table 2: Descriptive statistics: median values (in euros)

\begin{tabular}{lrrrrr}
\hline & 2007 & 2008 & 2009 & 2010 & 2011 \\
\hline Number of DGAs & 303611 & 317051 & 330222 & 335411 & 379354 \\
Number of firms & 163488 & 203404 & 229212 & 254079 & 264795 \\
Gross labour income (if $>0)$ & 43542 & 44291 & 44616 & 44437 & 43883 \\
Dividends (if $>0$ ) & 83000 & 25919 & 29411 & 29825 & 30065 \\
Equity of the firm & 155462 & 161558 & 163842 & 167121 & 170717 \\
$\Delta$ Equity of the firm & & 5608 & 5843 & 3951 & 2398 \\
\hline
\end{tabular}

\section{Bunching of wage income around the minimum reference wage}

DGAs have an incentive to minimise the (virtual) wage income they declare in order to avoid the progressive taxation of labour income. We analyse the distribution of gross wage income, as found in the database on personal income taxes. This database might specify several sources of labour income but we cannot identify whether a DGA earns income from several firms or that he works as an employee in other firms. We therefore 
drop DGAs reporting more than one source of labour income. Figure 3 clearly shows that this distribution strongly peaks around the 'minimum' reference wage. The size of the discontinuity is estimated using the approach proposed in McCrary (2008). This non-parametric method estimates two separate local linear weighted regressions, one for each side of the threshold. The size of the discontinuity is estimated as the log difference between the estimated densities close to the threshold. The tests reported in Table 3 confirm the findings of the visual inspection of Figure 3: all discontinuities are large and significant with a positive sign indicating that the bunch is just after the kink. ${ }^{7}$ A value of 1 (or 100\%) means that the density at the peak is twice as large as the density just before the peak.

We want to make some remarks on the bunching results. First, it might be surprising to find many incomes below the 'minimum' level. This could be explained by DGAs who have worked only part of the year or part of the week. Second, the bunching is not only due to tax arbitrage. In a number of cases the business income (before corporate taxes) will be lower than the minimum reference wage and the DGAs may want to avoid the cost to prove this to the tax authority and hence they will report the minimum. In fact, they do not need to take this wage out of their companies. The box 1 taxes over this virtual labour income are still due. Third, the imputation rules were relaxed in the crisis years 2009 and 2010. The DGAs owning a firm suffering from a lower turnover than in (the first half of) 2008 were allowed to reduce the minimum reference income in proportion. As a result, we would expect a smoother distribution and a smaller discontinuity for both years. We indeed find the smallest discontinuity in 2010 but in 2009 we find the highest discontinuity. Finally, the findings are robust to other values of the bin size and bandwidth.

The bunching at the minimum reference wage may represent under- or overreporting. Underreporting occurs when the owner managers want to avoid labour income taxation and overreporting when they want to avoid the cost of convincing the tax authority that their wage income is below the minimum reference. Thus government faces a trade-off with determining the level of minimum reference wage. An increase of the level will yield a tax revenue gain from the underreporting DGAs. Such an increase however, may induce overreporting DGAs to accept the compliance cost and to report their lower wage incomes.

\footnotetext{
${ }^{7}$ Distributions around the 'minimum' reference wage' are presented for all years in Figure A.1.
} 
Table 3: Bunching at the minimum reference wage income

\begin{tabular}{rrrrr}
\hline year & obs. $^{a}$ & threshold & discontinuity $^{b}$ & std. error \\
\hline 2007 & 53774 & 40000 & 0.887 & 0.031 \\
2008 & 55699 & 40000 & 0.747 & 0.027 \\
2009 & 58818 & 40000 & 0.962 & 0.027 \\
2010 & 59632 & 41000 & 0.685 & 0.024 \\
2011 & 68387 & 41000 & 0.829 & 0.024 \\
\hline
\end{tabular}

${ }^{a}$ Wage income $>30000 \&<50000$ euro. ${ }^{b} \log$ difference in height.

Figure 3: Bunching at the minimum reference wage income (2010)

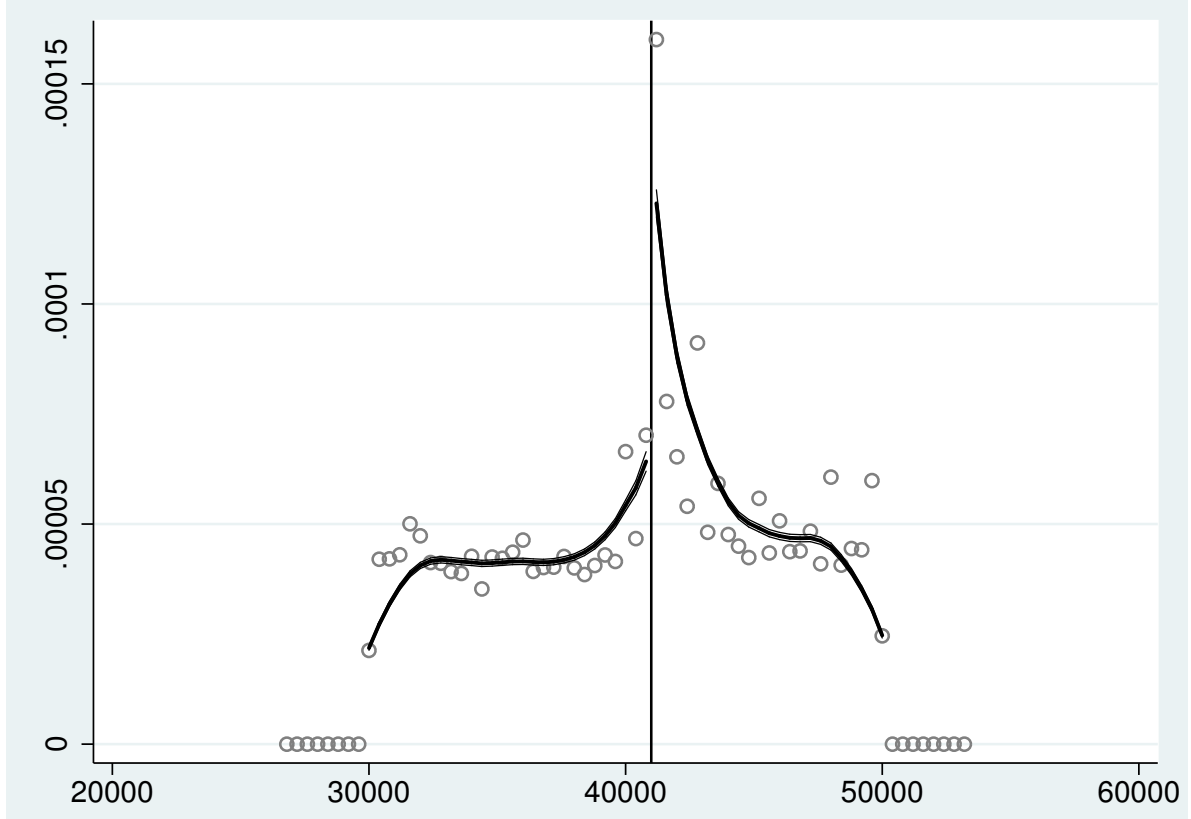

Note: bin size $=400$, bandwidth $=3000$. 


\section{Bunching of labour income tax base around the tax cut- offs}

In the previous section, we showed that relatively many DGAs declare the minimum labour income. Although the rules on the reference wage restrict DGAs in reporting any labour income, there are still opportunites to avoid having a taxable income in higher tax brackets. Figure 4 shows the distribution of taxable labour income (after all deductions). The peak around 10,000 euro mainly includes DGAs with a fiscal partner who receive a public pension while the red lines indicate the three tax brackets cut-offs.

We now focus the analysis on the last cut-off, at which the marginal tax rate is increased from $42 \%$ to $52 \%$. This is a considerable increase at which we might expect bunching. As explained in more detail in Section 2.3, it becomes more profitable to distribute income as dividend than as labour income in the higest tax bracket of $52 \%$. For labour income in the lower tax brackets distributing dividends is less attractive than raising labour income. Figure 5 shows a striking pattern at the last cut-off that is found in all years: the density is rather stable in a range of 5000 euro below and above the cut-off, except for a large peak at the cut-off. ${ }^{8}$ The McCrary-estimates in Table 4 confirm that the density falls discontinuously when the tax base passes the threshold, indicated by the negative sign of the coefficients.

In addition, we estimate the excess mass and the elasticity of taxable income, as proposed by Saez (2010) and extended by Chetty et al. (2011) ${ }^{9}$. The excess mass is expressed as the number of DGAs around the kink in terms of the average height of the counterfactual distribution in this interval. The estimate of the excess mass is large and significant for each year. Saez (2010) shows that the elasticity of taxable income is proportional to the excess mass around the kink. The elasticity of the base of box $1(B)$ with respect to the net-of-marginal-tax rate $(1-\tau)$ is approximated by:

$$
\epsilon=\frac{\partial \ln B}{\partial \ln (1-\tau)} \simeq \frac{b}{B^{*} \ln \left(\left(1-\tau_{1}\right) /\left(1-\tau_{2}\right)\right.}
$$

where $B^{*}$ denotes the threshold ${ }^{10}, b$ the excess mass, $\tau_{1}=42 \%$ and $\tau_{2}=52 \%$. The significantly estimated elasticity ranges between 0.06 and 0.11 .

\footnotetext{
${ }^{8}$ Distributions around the last tax cut-off are presented for all years in Figure A.2.

${ }^{9}$ We used the Stata program bunch_count, downloadable at www.rajchetty.com.

${ }^{10}$ The threshold in the equation is measured in units of the bins and should therefore be divided by 100 ; see Bastani and Selin (2013).
} 
Figure 4: Frequency labour income tax base (2010)

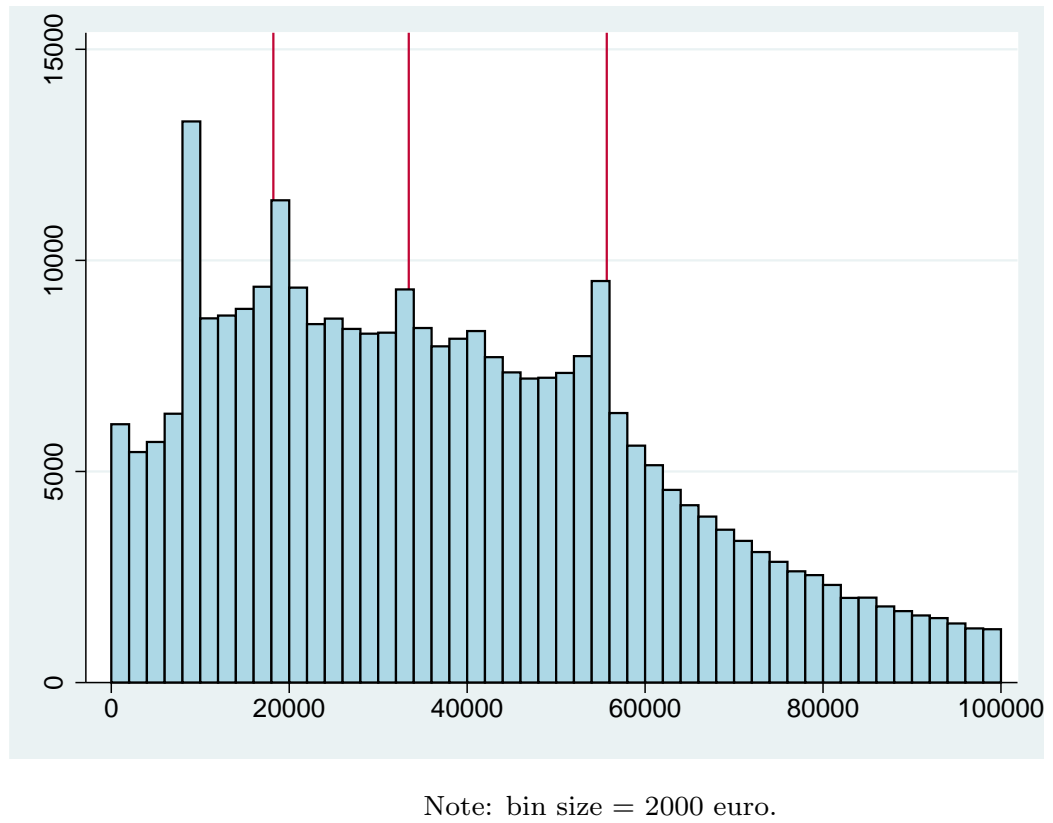

Figure 5: Bunching of the labour income tax base around last tax bracket (2010)

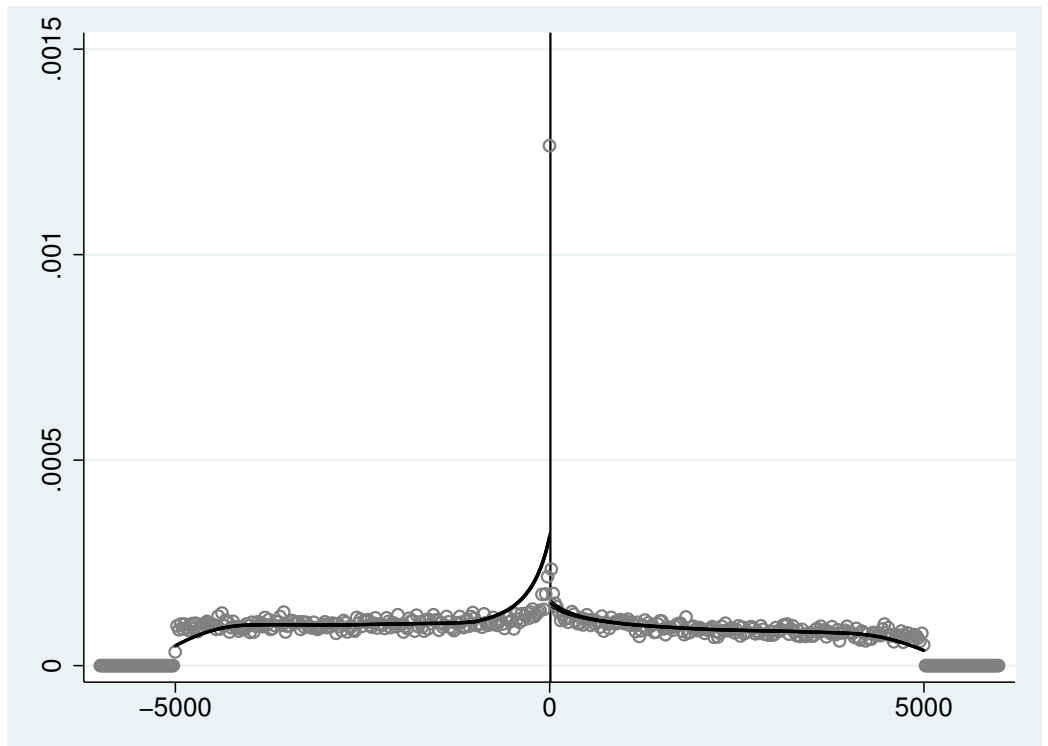

Note: bin size $=50$, bandwidth $=1000$. 
Table 4: Bunching of the labour income tax base around last tax cut-off

\begin{tabular}{lrllllll}
\hline year & threshold & \multicolumn{2}{l}{ discontinuity $^{a}$} & \multicolumn{2}{l}{ excess $^{2}$ mass $^{b}$} & \multicolumn{2}{l}{ elasticity } \\
\hline 2007 & 53064 & -0.727 & $(0.039)$ & 8.926 & $(2.518)$ & 0.089 & $(0.025)$ \\
2008 & 53860 & -0.701 & $(0.037)$ & 6.952 & $(1.774)$ & 0.068 & $(0.017)$ \\
2009 & 54776 & -0.869 & $(0.035)$ & 11.06 & $(2.051)$ & 0.107 & $(0.020)$ \\
2010 & 54367 & -0.743 & $(0.035)$ & 6.466 & $(1.898)$ & 0.063 & $(0.018)$ \\
2011 & 55694 & -0.833 & $(0.033)$ & 9.864 & $(2.155)$ & 0.094 & $(0.020)$ \\
\hline
\end{tabular}

${ }^{a}$ McCrary estimate: log difference in height, bin size $=25$, bandwidth $=1000$.

${ }^{b}$ bin size $=100$, excluded region $=5 \mathrm{k}$; total range $=15 \mathrm{k}$ left and right of the threshold, degree polynomial fitting conterfactual $=6$.

${ }^{c}$ tax rate increases from $42 \%$ to $52 \%$.

We interpret the findings in equation (1) as the outcomes of a tax kink and not of a kink in the underlying wage distribution as in Chetty et al. (2011). For various reasons we have no reason to believe that there is a kink in the wage distribution of the DGAs. First, because about $90 \%$ of the DGAs are self-employed their reference wages should be at least $70 \%$ of the comparable wage of a corresponding job. The criterium that the wage should be higher than the wage of the best-paid employee is thus hardly relevant. Second, reference wages differ because the activities of DGAs differ a lot from each other. Third, there is no institutional reason why the references wages would bunch at 1/0.7 times 55,000 euro (the beginning of the highest tax bracket).

According to Figure 4 there is a modest peak around the labour income tax base at 32,738 euro. This is the second tax cut-off. For people below the age of 65 , the tax rate is only raised by $0.05 \%$ to $42 \%$. This negligible increase in the tax rate cannot explain any bunching at all. However, for those aged 65 and above the tax rate increases from $17 \%$ to $42 \%$. Some further analysis shows that a part of the modest peak in Figure 4 is indeed explained by DGAs aged 65 and older, but not completely. We do not have sufficient data for calculating the excess mass and elasticity for this group. The income threshold of 32,738 euro is also the threshold for employees and DGAs to pay the health insurance premium (until 2011). Incomes above the threshold do not pay this premium. This disturbs the bunching analysis of the increase in the tax rate at his point and is therefore not discussed further.

The peak at 18,218 euro, the first tax cut-off, seems at first sight of similar size to the 
last cut-off. ${ }^{11}$ The increase in the tax rate varies from $7.75 \%$-points in 2007 to $8.95 \%$ points in 2011. Table A.1 in the annex shows that the exces mass is on average somewhat smaller than for the last tax cut-off and the standard errors are larger. As a result, the excess mass and the accompayning elasticity are only statistically significant in 2008, 2009 and 2011 (at the $90 \%$ significance level).

The finding that relatively many DGAs respond to the increase of the marginal tax rate of $10 \%$ points at the last tax cut-off suggests that DGAs can use inexpensive options to reduce their total tax burden. In line with the analysis in le Maire and Schjerning (2013), we explore how DGAs avoid the top tax rate in box $1 .{ }^{12}$ A first possibility is that DGAs shift 'excess' labour income in box 1 to capital income in box 2 . We therefore study the dividends received by DGAs who reported taxable labour income around the top tax cutoff. ${ }^{13}$ The left panel of Figure 6 presents the fraction of DGAs in bins around the threshold who received strictly positive dividends (pooled from 2008 to 2011). Unexpectedly, this fraction does not peak at the threshold but remains rather stable left of the threshold. The remaining possibility is that profits are not distributed but retained by the firm. The right panel indeed demonstrates that the fraction of DGAs who own a firm with increasing wealth (including pension reserves) peaks at the threshold, in particular in a window 2000 euro below and above the cut-off. As also found by le Maire and Schjerning (2013), intertemporal shifting seems to be the favoured option to reduce the tax burden (around the top tax cut-off).

\footnotetext{
${ }^{11}$ With the given bin size, the peak seems at the wrong side of the threshold. When a smaller bin size is used, the expected fall in the density is found; see the results in Table A.1.

${ }^{12}$ In comparison to our study, le Maire and Schjerning (2013) can distinguish between retained earnings and pension contributions, but they do not consider dividends as a margin of income shifting.

${ }^{13}$ To avoid the complexities arising from decision making by multiple owners, we restrict the sample to firms with single owners
} 
Figure 6: Fraction of DGAs having strictly positive dividends (left) and an increase in firm's wealth (right). Subsample of single owners with a base box 1 centered around the top tax cut-off over the years 2008-2011
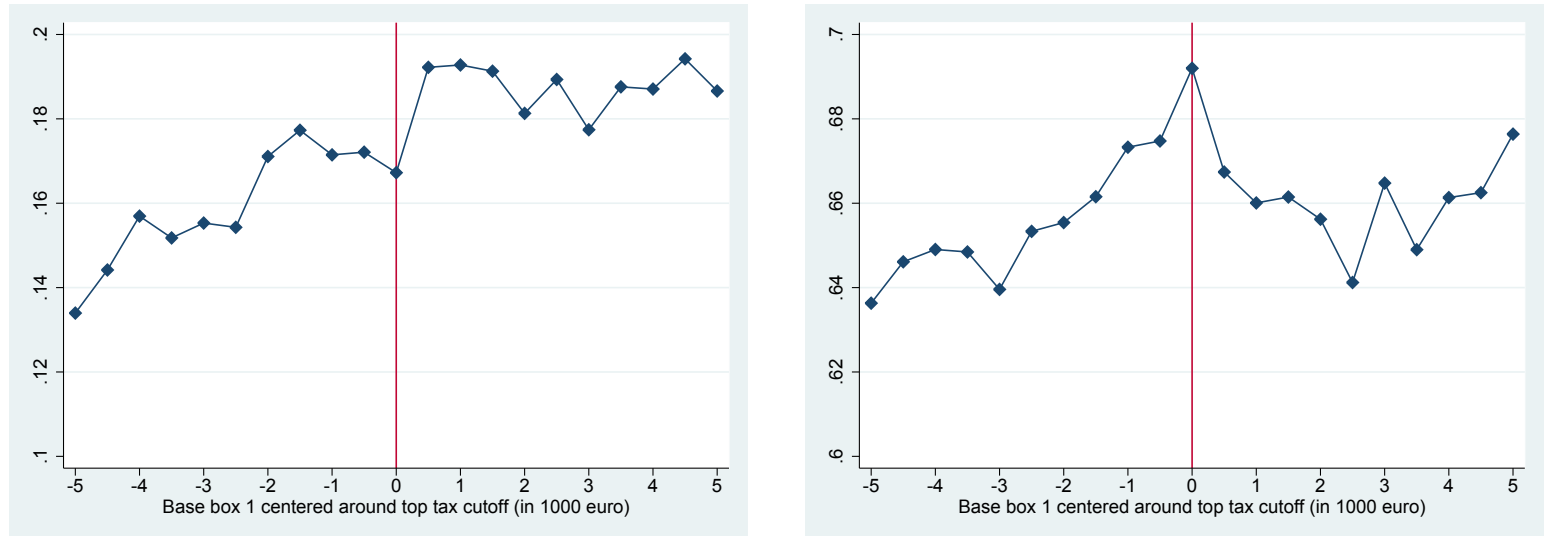

Note: bin size $=500$ euro. Number of observations ranges from 3404 in the first bin to 5555 in the 'bunching' bin and 2642 in the last bin.

Figure 7: Cumulative distribution of earned income of DGAs who report taxable labour income between 5000 euro below and above the top tax cut-off (2010)
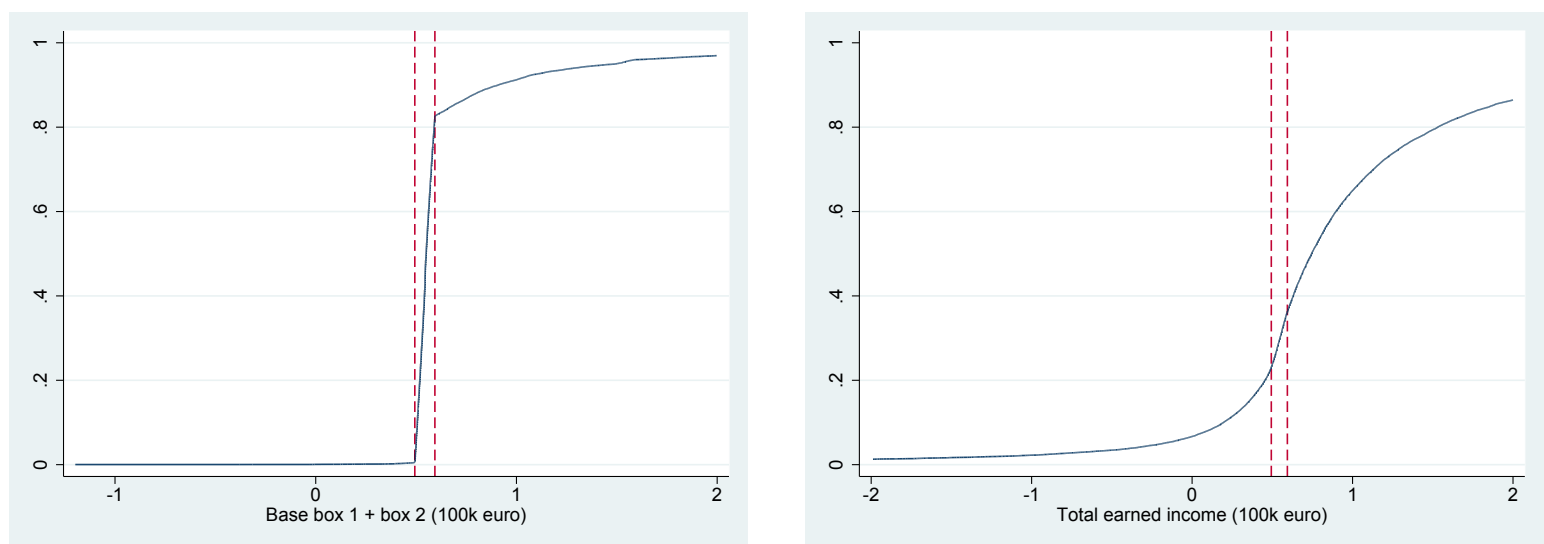

Note: total earned income $=$ base box $1+$ base box $2+$ change in firm's equity. Dotted lines give the 5000 euro window around top tax cut-off in box 1. 
As le Maire and Schjerning (2013), we also illustrate the amount of income shifting. First we focus on atemporal income shifting between wage income and dividend income. Earned income is the sum of the base of box 1 and the base of box 2. The left panel of Figure 7 plots the cumulative distribution of this income measure for the subsample of DGAs with a wage income from 5000 euro below to 5000 euro above the cut-off (of 54,367 euro) in 2010. The dotted lines indicate this region. If earned income would only be wage income the cumulative earned income distribution would increase from 0 to 1 between the dotted lines. This would also result in the extreme case without any shifting from labour income to dividends: earned income would equal the base of box 1. Because dividend income is not negative, the earned income distribution has no mass to the left hand of the dotted region. However, the distribution line hits the dotted line at 0.8 : for $80 \%$ of the selected DGAs the sum of both bases is found in the 'bunching' region. This implies that atemporal income shifting is not intensively applied by this group of DGAs. Only $20 \%$ pays out dividends such that earned income exceeds 59,367 euro.

In the second step we concentrate on intertemporal income shifting by extending the definition of earned income with the change in the equity value of the firm (corporate income taxes are excluded). The distribution in the right panel shows that more than $60 \%$ of the DGAs have earned income above the maximal taxable labour income $(59,367$ euro) included in this subsample. This supports the conclusion that a large part of total income is not paid out and taxed as labour income. For about $20 \%$ of the DGAs the value of own equity diminished in 2010 (maybe due to the crisis), which explains the increasing slope of the distribution to the left-hand side of the dotted region. ${ }^{14}$

\section{Results for the taxation of dividends of DGAs}

Dividend income of DGAs, including the sales of shares is taxed in box 2 at a flat rate of $25 \%$ (except in 2007). If profits are not distributed but accumulated in a firm's wealth, box 2 taxes can be deferred. As a result, $85 \%$ of the DGAs decided not to distribute profits in 2010. The low frequency of dividend payments is even better illustrated if we pool the observations over all years; see Table 5 . We have in total 619,489 unique DGAs in the dataset. The rows indicate how many times a DGA is observed in the pooled dataset; the columns indicate how many times he declared a (strictly) positive base in box 2 . The last row shows that the majority of DGAs (71.1\%) never declared dividend income during these years. It is most informative to consider a balanced panel, given by the row with 5

\footnotetext{
${ }^{14}$ Similar patterns are found in Figure A.3 and A.4 for the selection of DGAs who declared a taxable income around the first tax cut-off.
} 
observations. From the DGAs that we observe in all years, $57.8 \%$ declare a positive taxable income in none of the years considered and $19.4 \%$ only declare it once. ${ }^{15}$ Only $3.6 \%$ has dividend income in every year. The distribution of the base of box 2 (if strictly positive) in 2010 is presented in Figure 8; similar distributions are found for the other years. The peaks indicate round number bunching, as thresholds do not apply (after 2007).

The temporary reduction of the tax rate in box 2 in 2007 can be exploited to assess the strong responses by the DGAs. Imposing a lower rate of $22 \%$ on distributed profits until $250 \mathrm{k}$ euro caused a remarkable increase in tax revenues in box 2. Figure 9 shows that after an anticipatory drop in 2006, tax revenues more than doubled in 2007 before returning to a rather stable level in later years. This is a somewhat higher level than before the peak, which makes it difficult to assess whether firms did distribute their profits earlier in response to the lower tax rate. The strong reaction of DGAs is clearly illustrated in Figure 10 which shows the distribution around the threshold of 250k euro in 2007 (left axis). Almost all DGAs are found in the 1000 euro-bin before the threshold (21,771 DGAs are located exactly at the kink). ${ }^{16}$ This stands in sharp contrast to the distribution in 2008, after the two-rate structure was abolished (right axis). DGAs are now distributed over the whole interval and although there is round number bunching at $250 \mathrm{k}$ euro, the peak is at a much lower level (365 DGAs).

Table 5: Number of observations of base box 2 in pooled dataset

\begin{tabular}{lrrrrrrr}
\hline $\begin{array}{l}\text { \# obs }>0 \\
\text { \# obs. }\end{array}$ & 0 & 1 & 2 & 3 & 4 & 5 & Total \\
\hline 1 & 139,230 & 26,319 & & & & & 165,549 \\
2 & 66,185 & 12,671 & 7,600 & & & & 86,456 \\
3 & 54,857 & 10,426 & 4,895 & 3,687 & & & 73,865 \\
4 & 58,610 & 13,026 & 5,818 & 3,260 & 2,626 & & 83,340 \\
5 & 121,519 & 40,781 & 20,098 & 12,090 & 8,256 & 7,535 & 210,279 \\
Total & 440,401 & 103,223 & 38,411 & 19,037 & 10,882 & 7,535 & 619,489 \\
\hline
\end{tabular}

\footnotetext{
${ }^{15}$ Most of the DGAs in the balanced panel who declared only once $(40,781)$ are observed in $2007(23,062)$.

${ }^{16}$ As a consequence, the counterfactual distribution cannot be estimated. Furthermore, the structural elasticity cannot be derived since the DGAs knew that the lower tax rate was temporary.
} 
Figure 8: Frequency base box $2(>0)$ in 2010

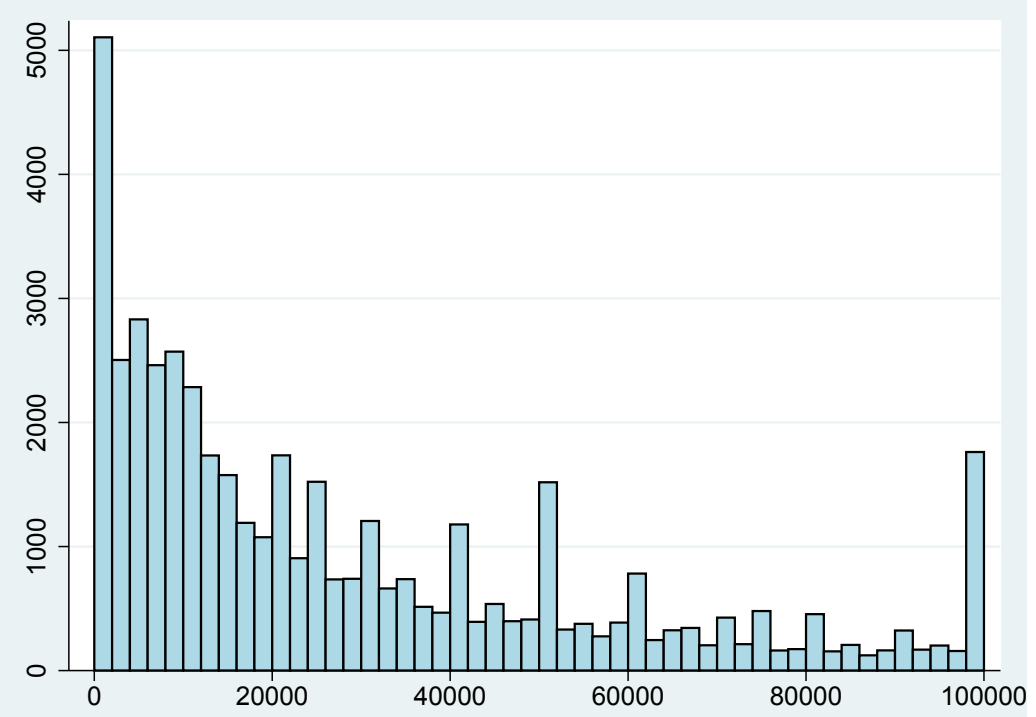

Note: bin size $=2000$ euro.

Figure 9: Tax revenues of box 2 (in billion euro)



Source: Ministry of Finance (2014a) 
Figure 10: Distribution of base box 2 around 250k euro (2007 en 2008)

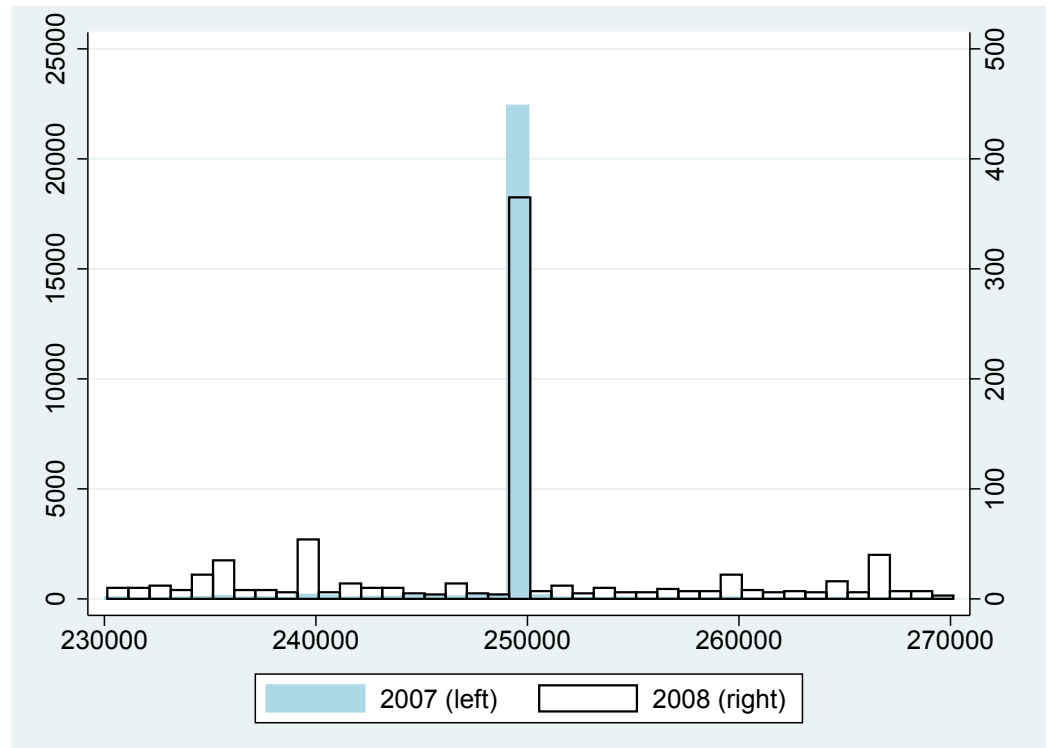

Note: bin size $=1000$ euro.

The profit distribution behaviour of DGAs suggests that not all profits are distributed and accordingly taxed. Therefore, we compute an effective tax rate on dividend income of DGAs. This taxation can be deferred but must be paid ultimately, for instance with the final sale of the shares of the company. However, tax can be exempted in case of migration of the DGA to another country or of succession. When there is no possibility of tax avoidance, and ignoring time discounting, the effective tax rate over the lifetime of a DGA-company relation should equal the statutory rate of $25 \%$. The effective rate is the ratio of taxes actually paid in box 2 and the tax base. The lifetime tax base equals the sum of (the individual share of) the distributed profits of the company for the duration of the ownership plus the final value of the shares (corrected for the initial investment and possible subsequent capital injections). The final value reflects the accumulated nondistributed profits, after corporate taxes, and the value of intangible assets (like goodwill). By taking a lifecycle tax base the lock-in effect of the box 2 tax is, in principle, eliminated.

However, the time span of our data set is too short to cover the lifetimes of DGAcorporations. Therefore we resort to a cross-section: the effective tax rate is computed by year. This approach is not uncommon. The European Commission and Eurostat (2014) present effective tax rates by year, based on national accounts data, for instance for several components of capital taxation. Zucman (2014) uses cross-sections to find a measure of the lock-out effect of foreign profits in the corporate taxation of US firms. Taxation of 
these profits is due only upon actual repatriation and can therefore be deferred. On the accumulated profits kept outside the US rests a tax claim; the same holds for the accumulated profits kept within the company of the DGA. The assumption of using a cross-section is that in a single year there will be a similar structural pattern of profits distributions, accumulation and final sales, as there is intertemporally.

The numerator for the effective rate is the total box 2 tax revenue in a year. The denominator represents economic profits which we approximate by the box 2 base plus the change in equity of all firms in our sample. The sample is restricted to firms with a single owner. The effective tax rate is $15.0 \%$ for $2008,15.4 \%$ for $2009,17.4 \%$ for 2010 and $13.9 \%$ for $2011 .{ }^{17}$

These outcomes suggest that not all profits are taxed because firms can avoid taxation or could defer it to some extent. The few years that we have available may not be representative of the lifecycle DGA non-labour income taxation. One indication is the growing number of DGAs and firms, see Table 2, suggesting that the population has a growing share of young firms which may be less likely to distribute profits. Another limitation is that we do not correct for capital injections which increase equity but are outside the tax base, thus potentially underestimating the true rate. Finally, the restriction to single owners may imply that we miss out on parent-child combinations for whom tax exemptions exist with succession, which would lead to an overestimation.

\section{Determinants of profit distribution}

We aim to better understand the determinants of both the decision to pay out dividends and the size of these dividends. For this reason we apply a regression analysis on the dividend behaviour of DGAs. Since the tax parameters do not change much over the years 2007 to 2011 (see Section 2) we use the differences between the DGA-firms for identification.

We have merged the two data sets discussed in Section 3 and selected the firms for which we have information on the owner (DGA) salary, profit distribution and own equity including provisions. This results in about 150,000 observations by year.

We use a Heckman selection model in which the firms of the DGA are selected which distribute dividends in a year. Because the size of the dividends is censored at the left we have a concentration of zero-value observations. Heckman (1979) proposed a two-stage estimation procedure using the inverse Mills ratio to take account of this selection bias.

\footnotetext{
${ }^{17}$ The number of observations is $41,342,43,544,58,404$ and 83,676 , respectively. When observations with negative profits are excluded the effective tax rates are about $2 \%$ points lower.
} 
Possible determinants are own equity (including provisions) in log, the ratio of foreign to own equity, owner salary in log, a dummy for pension provisions, the size of pension provisions in $\log$ and the number of DGAs in a firm. We expect that own equity has a positive effect on the probability for distributing profits. Firms with hardly any equity are not in a position for distributing dividends and firms with relatively low equity will probably retain profits to improve the liquidity of the firm or pension provisions. We have no clear expectation of the effects of owner salary, these could be positive or negative. On the one hand, DGAs have a tax incentive for distributing profits instead of salary in the high tax bracket. This suggests a positive effect, but the legal conditions which govern DGA salaries could be tight. Moreover, if profits are high, DGAs could decide to pay out a high salary and dividends. On the other hand, if owner salaries are high due to the legal conditions of the reference wage, this could be a reason for firms not to distribute profits. We include two variables for pension provisions in order to distinguish between the decision of having a pension provision and its magnitude. Large provisions could indicate that the firm is mainly used for building up pension wealth and distributing pension income (taxed in box 1) to the DGA after retirement. Then we expect a negative coefficient. The number of DGAs of a firm could have a positive or negative effect (as discussed later). We also include a sector dummy, which is one if the firm is active in the financial sector and zero otherwise. We use this variable as the exclusion restriction as it is significant in explaining the decision for distributing profits but not its size.

We cannot include the tax rates because these are constant in the data period (except for the lower box 2 rate in 2007), so this is already captured by the year dummies. In order to reduce the possible endogeneity between DGA decisions on the wage level, equity and dividends, all explanatory variables are lagged by one year. So we estimate the size of the dividends in 2008 to 2011 using explanatory variables from 2007 to 2010.

Table 6 presents three sets of regressions. Each set consists of a regression explaining the size of the dividends and the selection equation on the decision to distribute dividends or not. Regression (1) shows that the size of own equity has a significant positive effect on the decision for distributing profits, but the ratio of foreign to own equity has no significant impact. Firms with pension provisions are more willing to distribute dividends, but this effect is smaller if the pension provisions are larger. It might be the case that firms without an explicit pension provision try to raise own equity as implicit pension provision. Wages have a small negative effect on the decision to distribute profits. If reference wages are pushed upwards by the legal rules it makes sense that firms do not want to distribute profits. 
Table 6: Determinants of dividend behavior of DGAs

\begin{tabular}{|c|c|c|c|c|c|c|}
\hline \multirow{2}{*}{$\begin{array}{l}\text { regression sets } \\
\text { variables }\end{array}$} & \multicolumn{2}{|l|}{ 1. All } & \multicolumn{2}{|c|}{ 2. Current wage +} & \multicolumn{2}{|c|}{ 3. Equity quartiles } \\
\hline & size & probit & size & probit & size & probit \\
\hline \multirow[t]{2}{*}{ Lag ln own equity } & $0.517^{* * *}$ & $0.057^{* * *}$ & $0.518^{* * *}$ & 0.057 & & \\
\hline & $(0.006)$ & $(0.001)$ & $(0.006)$ & $(0.001$ & & \\
\hline \multirow[t]{2}{*}{ Dummy 2nd quartile } & & & & & $0.358^{* * *}$ & $0.089^{* * *}$ \\
\hline & & & & & $(0.024)$ & $(0.002)$ \\
\hline \multirow[t]{2}{*}{ Dummy 3rd quartile } & & & & & $0.835^{* * *}$ & $0.153^{* * *}$ \\
\hline & & & & & $(0.026)$ & $(0.002)$ \\
\hline \multirow[t]{2}{*}{ Dummy 4th quartile } & & & & & $1.734^{* * *}$ & $0.232^{* * *}$ \\
\hline & & & & & $(0.029)$ & $(0.002)$ \\
\hline \multirow{2}{*}{$\begin{array}{l}\text { Lag rat foreign } \\
\text { to own equity }\end{array}$} & $0.243^{* * *}$ & -0.001 & $0.249^{* * *}$ & -0.001 & $-0.000^{* * *}$ & -0.001 \\
\hline & $(0.033)$ & $(0.001)$ & $(0.033)$ & $(0.001)$ & $(0.000)$ & $(0.001)$ \\
\hline \multirow{2}{*}{$\begin{array}{l}\text { Lag dummy pension } \\
\text { provision }\end{array}$} & $-1.001^{* * *}$ & $0.114^{* * *}$ & $-1.000^{* * *}$ & $0.120^{* * *}$ & $-1.066^{* * *}$ & $0.107^{* * *}$ \\
\hline & $(0.074)$ & $(0.009)$ & $(0.074)$ & $(0.009)$ & $(0.076)$ & $(0.009)$ \\
\hline \multirow{4}{*}{$\begin{array}{l}\text { Lag ln pension } \\
\text { Equity } \\
\text { Lag ln owner salary }\end{array}$} & $0.062^{* * *}$ & $-0.015^{* * *}$ & $0.062^{* * *}$ & $-0.0150^{* * *}$ & $0.072^{* * *}$ & $-0.014^{* * *}$ \\
\hline & $(0.006)$ & $(0.001)$ & $(0.006)$ & $(0.001)$ & $(0.007)$ & $(0.001)$ \\
\hline & $0.033^{* * *}$ & $-0.002^{* * *}$ & $0.023^{* * *}$ & $-0.004^{* * *}$ & $0.038^{* * *}$ & $-0.004^{* * *}$ \\
\hline & $(0.003)$ & $(0.000)$ & $(0.002)$ & $(0.000)$ & $(0.003)$ & $(0.000)$ \\
\hline \multirow[t]{2}{*}{ Number of DGAs } & $0.087^{* * *}$ & $0.040^{* * *}$ & $0.090^{* * *}$ & $0.042^{* * *}$ & $0.086^{* * *}$ & $0.040^{* * *}$ \\
\hline & $(0.016)$ & $(0.002)$ & $(0.016)$ & $(0.002)$ & $(0.016)$ & $(0.002)$ \\
\hline \multirow[t]{2}{*}{ Dummy sector } & & $-0.012^{* * *}$ & & $-0.014^{* * *}$ & & $-0.013^{* * *}$ \\
\hline & & $(0.002)$ & & $(0.002)$ & & $(0.002)$ \\
\hline \multirow[t]{2}{*}{ Dummy year 2008} & $-0.026^{*}$ & $-0.034^{* * *}$ & $-0.030^{* *}$ & $-0.034^{* * *}$ & -0.013 & $-0.035^{* * *}$ \\
\hline & $(0.014)$ & $(0.002)$ & $(0.014)$ & $(0.002)$ & $(0.014)$ & $(0.002)$ \\
\hline \multirow[t]{2}{*}{ Dummy year 2009} & $-0.024^{* *}$ & $-0.015^{* * *}$ & $-0.023^{* *}$ & $-0.014^{* * *}$ & -0.010 & $-0.010^{* * *}$ \\
\hline & $(0.012)$ & $(0.001)$ & $(0.012)$ & $(0.001)$ & $(0.012)$ & $(0.001)$ \\
\hline \multirow[t]{2}{*}{ Dummy year 2010} & -0.001 & $0.005^{* * *}$ & -0.001 & $0.005^{* * *}$ & -0.010 & $0.009^{* * *}$ \\
\hline & $(0.001)$ & $(0.001)$ & $(0.01)$ & $(0.001)$ & $(0.010)$ & $(0.001)$ \\
\hline \multirow[t]{2}{*}{ Constant } & $3.538^{* * *}$ & & $3.511^{* * *}$ & & $9.369^{* * *}$ & \\
\hline & $(0.084)$ & & $(0.088)$ & & $(0.057)$ & \\
\hline \multirow[t]{2}{*}{ Mills ratio } & $0.144^{* * *}$ & & $0.148^{* * *}$ & & $0.055^{* *}$ & \\
\hline & $(0.009)$ & & $(0.009)$ & & $(0.016)$ & \\
\hline Observations & 82,655 & 455,841 & 82,653 & 455,810 & 83,061 & 462,110 \\
\hline
\end{tabular}

Note: All regressions are Heckman selections models with the size of dividends as dependent variable and a dummy whether dividends are paid out or not as dependent in selection equation. Coefficients in selection equation are marginal effects. Standard errors are in parentheses. ${ }^{* * *},{ }^{* *}$ and ${ }^{*}$ denote $99 \%, 95 \%$ and $90 \%$ statistical significance. + ln of current owner salary is the independent variable instead of lagged $\ln$ 
The number of DGAs also has a positive effect on the decision to distribute profits. The last effect seems to be opposite to Harju and Matikka (2014). They argue that concentrated ownership has more power for taking optimal tax decisions on income composition. In this case, increased ownership appears to open up a way to pay out more low-taxed dividends at the expense of salary (given the changes in the tax code). Our variable expressed as the number of DGAs, being the opposite of increased ownership, has a positive effect on dividends. An interpretation in line with Harju and Matikka (2014) is that, although retained earnings might offer the most tax-friendly option, exploiting this margin is more complicated for firms with more shareholders: emigration or inheritance is not possible or at least more complex than for firms with one or two shareholders. A more intensive dividend policy might therefore become the prefered option. The negative (positive) coefficients of the year dummies indicate that the share of firms distributing profits is lower (higher) compared to 2011. Firms in the financial sector are less willing to distribute profits.

The Mills ratio is statistically significant, suggesting that the selection equation has a significant impact on explaining the size of the dividends. Here also the size of own equity is important: the elasticity of dividend payments to own equity is about 0.50. A higher ratio of foreign to own equity also has a positive impact. It might be that firms are constrained in their own equity, such that paying out dividends is only possible with more debt (Vrijburg, 2015). Firms with a pension provision pay out lower dividends than firms without such a provision, but when the provisions are larger, the payments increase. A higher owner salary also has a positive impact on the size of the dividends. Finally, a higher number of DGAs per firm has also a positive effect on the size of dividends per firm (but not necessarily by DGA).

Instead of the owner salary of the previous year, we have also used this variable in the current year as an explanatory variable. This is presented in the second set of regressions. Overall, the effects are quantitatively similar to in regression (1), only the effect of the DGA salary on the dividend size is smaller. ${ }^{18}$

The last regression presents the results when the firms are split up in four, equal groups, depending on the size of own equity. The reason is that many firms have hardly any equity and we question whether these firms distribute any profits at all. We expect a smaller impact of own equity on the dividend decision than for firms which own more capital. We have constructed dummy variables indicating whether a firm belongs to that

\footnotetext{
${ }^{18}$ We have also estimated an IV probit model with the lagged wage as instrument for the current wage. The negative impact of the wage on the pay-out decision is slightly smaller than if the current wage is used as explanatory variable.
} 
part of the equity distribution. We have used these dummies as explanatory variables instead of the size of own equity and find that the size of the coefficient is significantly higher if the firm is in a higher equity bracket. In particular for firms in the highest equity bracket, own equity has a much larger impact on the decision to distribute profits and the size of the dividends.

The analysis suffers from a number of data limitations. The first is the limited number of years. This restricts the possibility of a panel or duration analysis on dividend behaviour. The second is the lack of major tax policy shifts between 2007 to 2011 which excludes the use of dif-in-dif techniques. These econometric techniques are in general more suitable for identifying behavioural reponses than panel analyses. Third, we miss data on the financial relations between the firm and the DGA. Many DGAs borrow from their firm, e.g. a mortgage. Moreover, many firms own (durable) consumption goods, which are also used for personal use, like cars, computers, telephones etc. Fourth, we miss data on the characteristics of firms and DGAs, such as age and comparable salaries from which reference wages are derived that could possibly be used for instrumenting wages or equity.

These limitations make us careful in emphasing these results. Nevertheless the size of own equity has a significant impact on both the decision to distribute profits and the size of the dividends. Also the number of DGAs, the owner salary, the economic sector and pension provisions have a significant impact on whether or not profits are retained.

\section{Discussion and concluding remarks}

Since the income tax reforms in 2001, the Netherlands has a unique system of boxes in income taxation. Wages are taxed progressively in box 1, capital income of owners of small corporations (DGAs) in box 2 and a fixed return on financial wealth is taxed in box 3 . In particular, DGAs have the possibility to pay themselves wages in box 1, which is governed by some rules, distribute profits (dividends) in box 2 or retain earnings as corporate wealth. For the first time, this paper uses individual data from tax forms to study the responsiveness of DGAs to the Dutch taxation system. We have unique data from 2007 to 2011. The tax parameters do not change much over these years but interestingly the tax rate on dividends (not exceeding 250,000 euro) was temporarily $22 \%$ in 2007 while it is $25 \%$ in the years before and after.

We report four main findings. The first is that the distribution of gross wage income strongly peaks around the 'minimum' reference level. Above this minimum level the tax authorities have to prove that the reported wages are too low, while below the minimum the DGAs have to motivate the low reported wages. We find significant bunching at the 
minimum references wages at 40,000 or 41,000 euro, depending on the year. According to the McCrary (2008) approach, the density at the peak is substantially larger than the densities before the peak, for all years.

The second finding is that taxable labour income bunches at the cut-offs of the tax brackets, in particular at the top tax bracket cut-off. The elasticity of taxable income ranges from 0.06 to 0.11 . It suggests that at least a number of DGAs have inexpensive options for reducing their tax burden. An alternative would be to shift income to box 2 , because the marginal tax rate on dividends is about 10 percentage points lower than in the higher wage income bracket. However, only $20 \%$ of all DGAs distribute profits in a given year. We find that the group of DGAs located around the top tax cut-off uses retained earnings (including pension contributions) as the primary channel to reduce the tax burden.

The third finding is the strong response to the temporary reduction of the tax rate on distributed profits in 2007 when the tax rate in box 2 was lowered from 25 to $22 \%$ for as long as the tax base does not exceed 250,000 euro. In $200730 \%$ of the DGAs decided to distribute profits, often exactly 250,000 euro, resulting in a tripling of the tax revenues in box 2 . Since almost no DGAs have paid dividends in the region around the threshold, we cannot estimate the size of the discontinuity.

Finally, we find that the size of own equity is an important determinant for deciding to distribute profits and the size of the dividends, although this result does not contribute to our understanding of the strong response in 2007. Also the owner salary, pension provisions, the number of owners and economic sector impact the pay-out decision.

Combining these findings it seems that DGAs are much more sensitive to changes in capital income taxation than to those in labour income taxation. That corresponds to the results of Harju and Matikka (2014). The results also show that retained earnings are a margin that is preferred more than distributing profits. Corporate owners could have various reasons for increasing equity such as liquidity restrictions, building up pension reserves, tax holidays and tax avoidance. The latter reason is the lock-in effect, which hampers the effectiveness of the capital gains taxation of box 2. However, it is not immediately clear to what extent delaying profit distribution reduces the lifetime tax burden for DGAs, as the retained income may show up in later or other tax bases. Without data over more years it is hard to draw firm conclusions on the motives of DGAs to pile up wealth in their corporations, or its consequences. Given the importance of the capital gains taxation and the strong responses we have found, this is certainly a research area to exploit in the future. 


\section{References}

Alstadsaeter, A. and Jacob, M. (2015). Dividend taxes and income shifting. Scandinavian Journal of Economics, forthcoming.

Bastani, S. and Selin, H. (2013). Bunching and non-bunching at kink points of the Swedish tax schedule. Journal of Public Economics, 109:3649.

Boadway, R. (2004). The dual income tax system an overview. CESifo DICE Report $3 / 2004$.

Chetty, R., Friedmann, J., Olsen, T., and Pistaferri, L. (2011). Adjustment costs, firm responses, and micro vs. macro labor supply elasticities: Evidence from Danish tax records. The Quarterly Journal of Economics, 126, 749-804.

Cnossen, S. (2014). Van Dijkhuizen en Mirrlees. Tijdschrift voor Openbare Financiën, 46(1):25-34.

Cnossen, S. and Bovenberg, L. (2001). Fundamental tax reform in the Netherlands. International Tax and Public Finance, 7, 471484.

Commissie inkomstenbelasting en toeslagen (2013). Naar een activerender belastingstelsel. Den Haag.

Crawford, C. and Freedman, J. (2010). Small business taxation. In Mirrlees, J., Adam, S., Besley, T., Blundell, R., Bond, S., Chote, R., Gammie, M., Johnson, P., Myles, G., and Poterba, J., editors, The Mirrlees Review, chapter 11. Oxford University Press.

Devereux, M., Liu, L., and Loretz, S. (2014). The elasticity of corporate taxable income: New evidence from UK tax records. American Economic Journal: Economic Policy, $6(2): 19-53$.

European Commission and Eurostat (2014). Taxation trends in the European Union. Eurostat statistical books.

Harju, J. and Matikka, T. (2014). The elasticity of taxable income and income-shifting: What is real and what is not? CESIFO Working Paper no. 4905.

Heckman, J. (1979). Sample selection bias as a specification error. Econometrica, 47:153161.

Jacobs, B. (2015). Belastingen op kapitaalinkomen in Nederland. Tijdschrift voor Openbare Financiën, 47(1):24-48. 
Kleven, H. and Schultz, E. (2014). Estimating taxable income responses using Danish tax reforms. American Economic Journal: Economic Policy, 6(4):271-301.

le Maire, D. and Schjerning, B. (2013). Tax bunching, income shifting and selfemployment. Journal of Public Economics, 107:118.

McCrary, J. (2008). Manipulation of the running variable in the regression discontinuity design: A density test. Journal of Econometrics, 142(2):698-714.

Ministry of Finance (2014a). Antwoorden op Kamervragen Miljoenennota 2015 (kamerstuk 22-9-2014). Den Haag.

Ministry of Finance (2014b). Bruto-nettotrajecten, bijlage 2 bij Brief over de winstbox. Den Haag, 3 juli 2014.

Saez, E. (2010). Do taxpayers bunch at kink points? American Economic Journal: Economic Policy, 2(3):180-212.

Sørensen, P. (2010). Dual income taxes: A Nordic tax system. In Claus, I., Gemell, N., Harding, M., and White, D., editors, Tax Reform in Open Economies, pages 78-108. Edward Elgar.

Van den Bos, A., de Groot, A., van Loon, P., Stoffer, S., and Tomesen, P. (2012). Elsevier $V P B$ Almanak. Elsevier Fiscaal.

Vrijburg, H. (2015). The deadweight loss from taxing small and medium-sized enterprises. IIPF conference, Dublin.

Zucman, G. (2014). Taxing across borders: Tracking personal wealth and corporate profits. Journal of Economic Perspectives, 28(4):121-148. 
Figure A.1: Bunching at the minimum reference wage income

(a) 2007

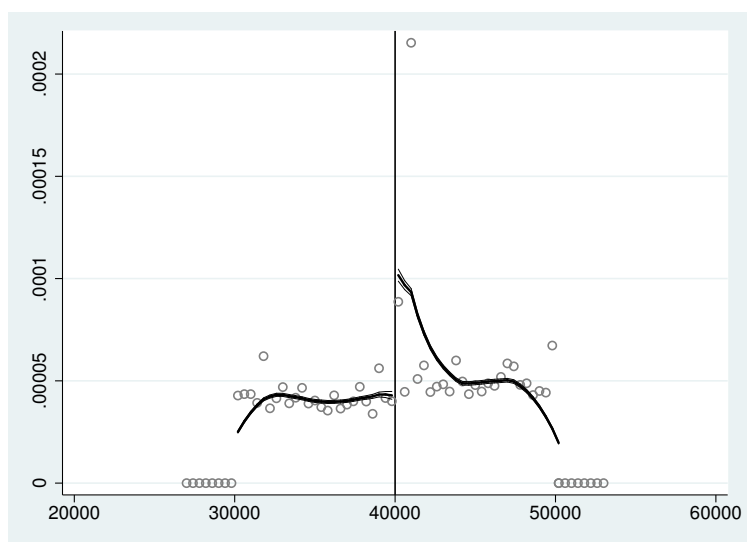

(c) 2009

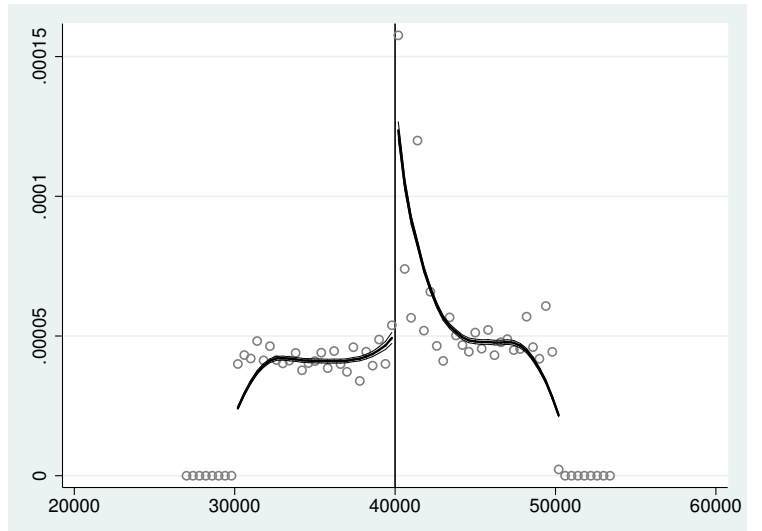

(e) 2011

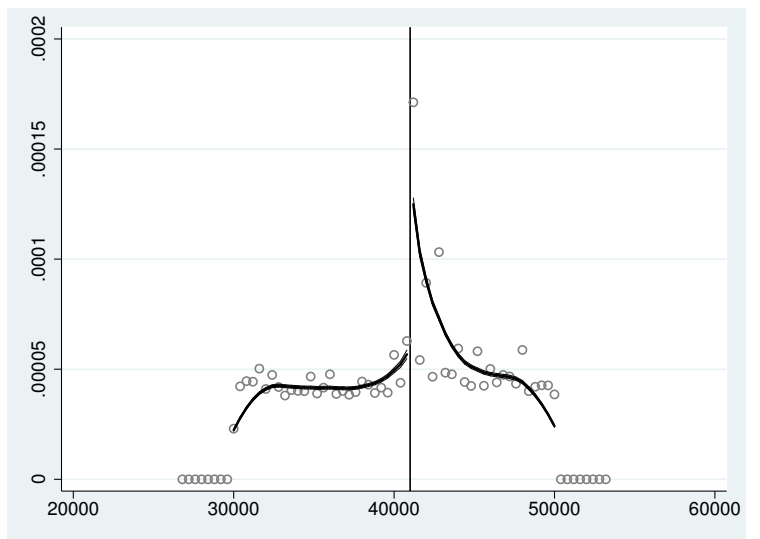

Note: bin size $=400$, bandwidth $=3000$. (b) 2008

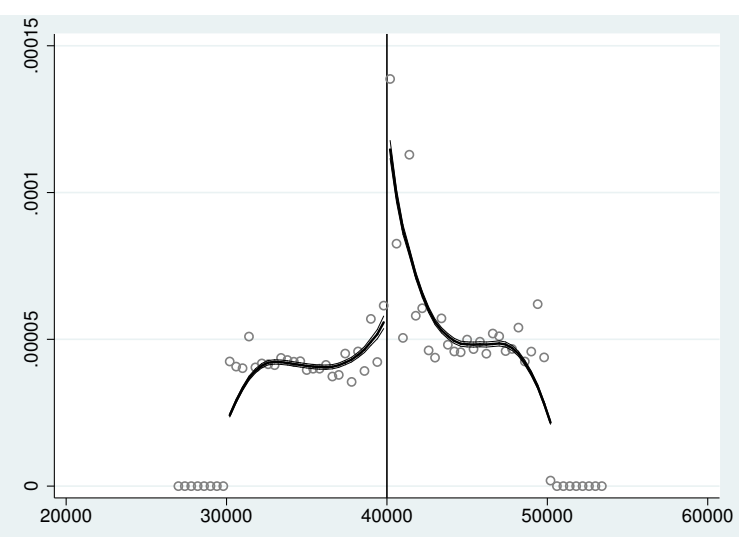

(d) 2010

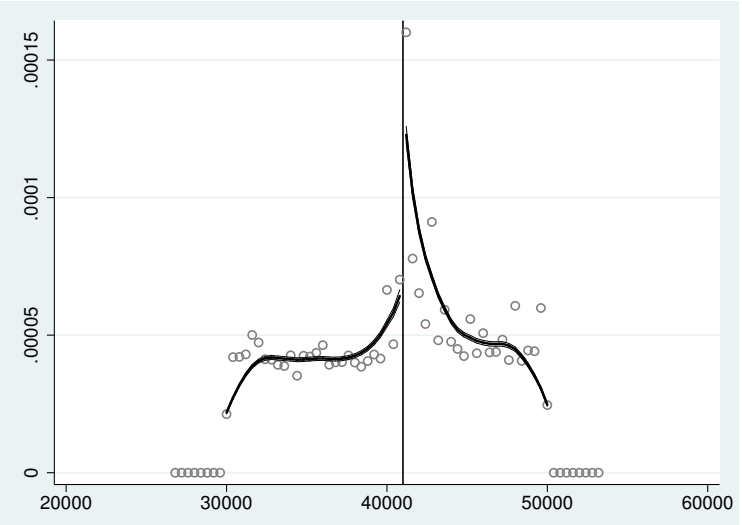


Figure A.2: Bunching of the labour income tax base around last tax bracket

(a) 2007

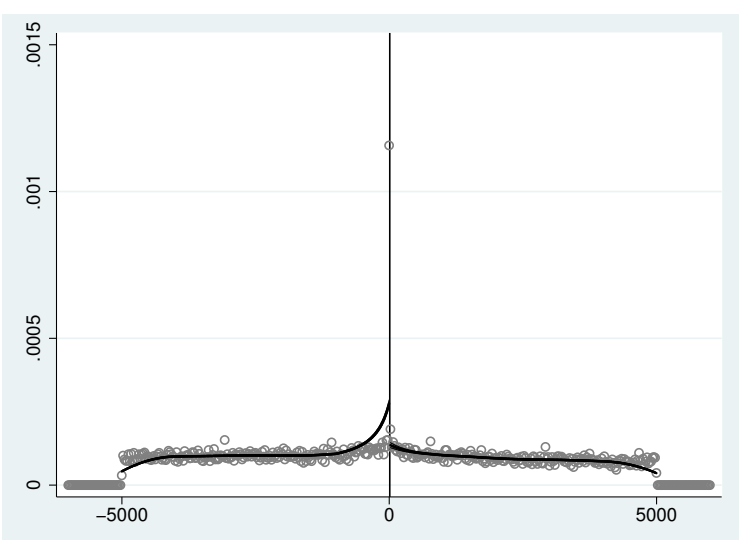

(c) 2009

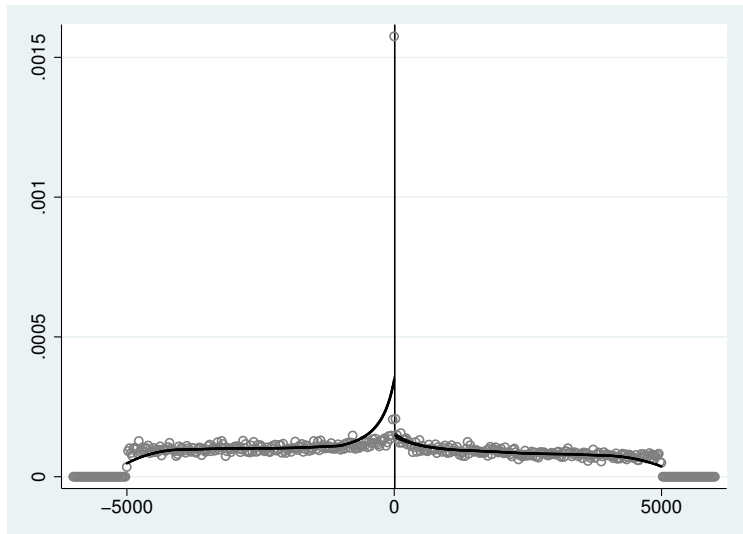

(e) 2011

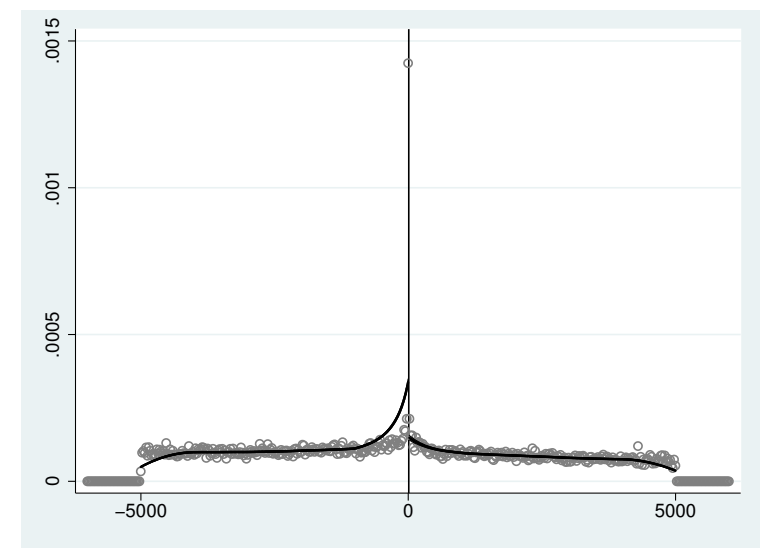

Note: bin size $=50$, bandwidth $=1000$. (b) 2008

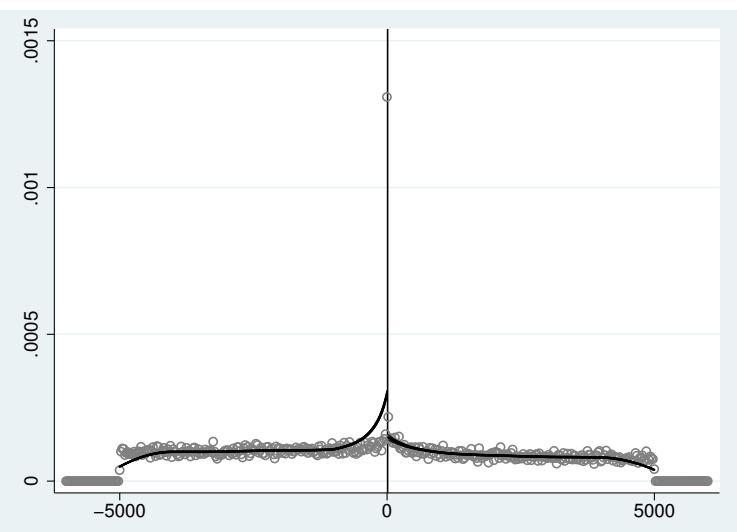

(d) 2010

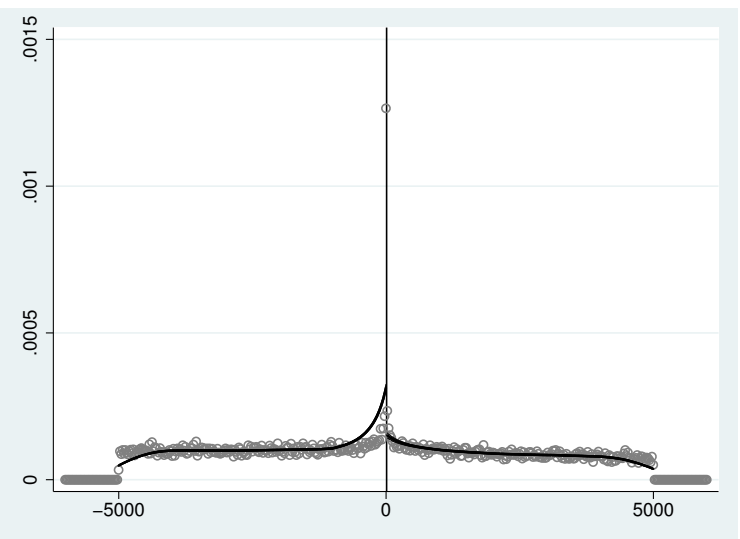


Figure A.3: Fraction of DGAs having strictly positive dividends (left) and an increase in firm's wealth (right). Subsample of single owners with a base box 1 centered around the first tax cut-off over the years 2008-2011
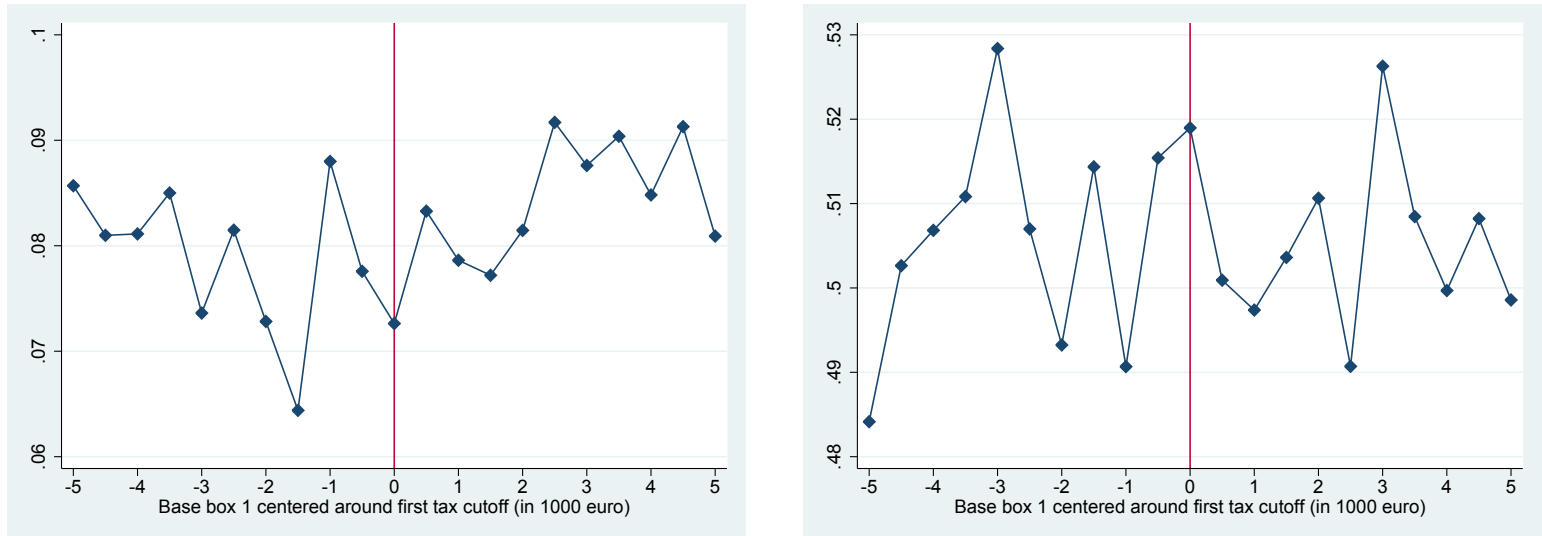

Note: bin size $=500$ euro. Number of observations ranges from 1167 in the first bin to 2451 in the 'bunching' bin and 1755 in the last bin.

Figure A.4: Cumulative distribution of earned income of DGAs who report taxable labour income between 5000 euro below and above the first tax cut-off (2010)
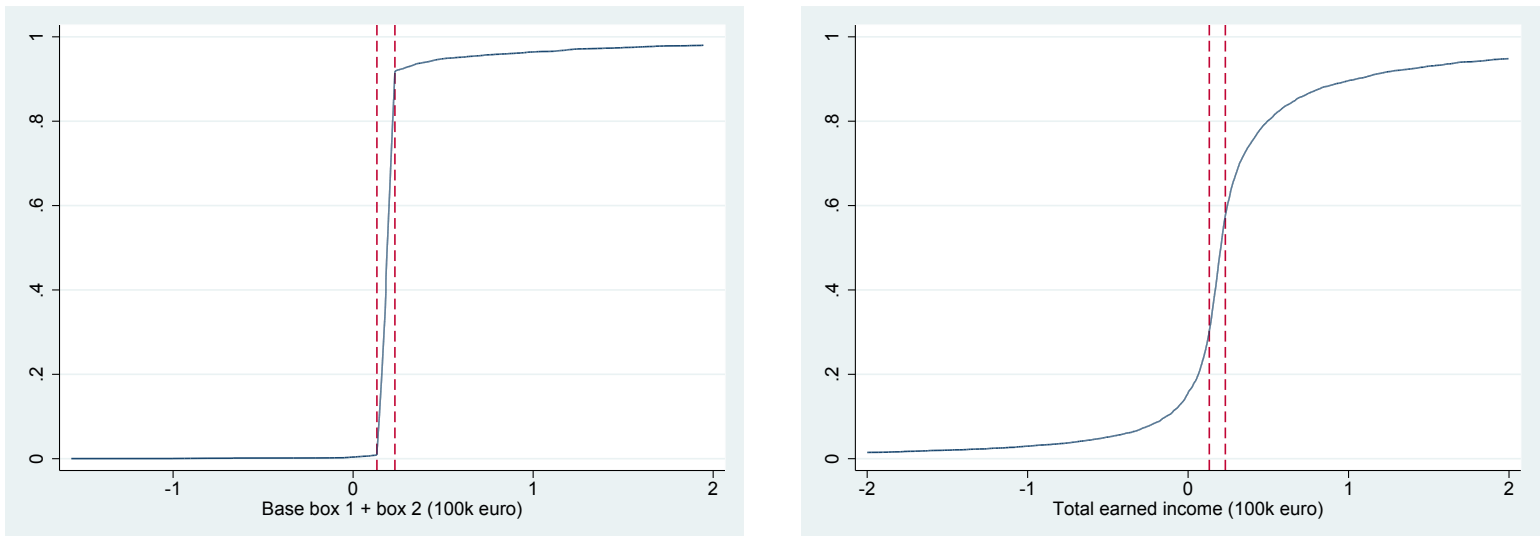

Note: total earned income $=$ base box $1+$ base box $2+$ change in firm's value. Dotted lines give the 5000 euro window around first tax cut-off in box 1 . 
Table A.1: Bunching of the labour income tax base around first tax cut-off

\begin{tabular}{lrllllll}
\hline year & threshold & \multicolumn{2}{l}{ discontinuity $^{a}$} & \multicolumn{2}{l}{ excess $^{2}$ mass $^{b}$} & \multicolumn{2}{l}{ elasticity } \\
\hline 2007 & 17319 & -0.465 & $(0.037)$ & 6.054 & $(3.961)$ & 0.141 & $(0.092)$ \\
2008 & 17579 & -0.406 & $(0.036)$ & 6.495 & $(3.286)$ & 0.139 & $(0.070)$ \\
2009 & 17878 & -0.532 & $(0.034)$ & 7.650 & $(3.777)$ & 0.157 & $(0.077)$ \\
2010 & 18218 & -0.621 & $(0.035)$ & 3.397 & $(3.180)$ & 0.068 & $(0.064)$ \\
2011 & 18628 & -0.414 & $(0.031)$ & 8.158 & $(4.259)$ & 0.153 & $(0.080)$ \\
\hline
\end{tabular}

${ }^{a}$ McCrary estimate: $\log$ difference in height, bin size $=25$, bandwidth $=1000 .{ }^{b}$ bin size $=50$, excluded region $=2.5 \mathrm{k}$; total range $=7.5 \mathrm{k}$ left and right of the threshold, degree polynomial fitting conterfactual $=6$.

${ }^{c}$ tax rate increase ranges from $7.75 \%$ in 2007 to $8.95 \%$ in 2011 . 

Publisher:

CPB Netherlands Bureau for Economic Policy Analysis

P.O. Box 80510 | 2508 GM The Hague

$\mathrm{T}$ (070) 3383380

March 2016 | ISBN 978-90-5833-723-8 